\title{
Stoichiometry of leaf nitrogen and phosphorus of grasslands of the Inner Mongolian and Qinghai-Tibet Plateaus in relation to climatic variables and vegetation organization levels
}

Received: 9 October 2015/ Accepted: 23 August 2016/Published online: 6 September 2016

(C) The Ecological Society of Japan 2016

\begin{abstract}
Nitrogen (N) and phosphorus (P) are most commonly the limiting essential elements that affect the functioning of plants and ecosystems. However, their stoichiometry in relation to climatic variables and vegetation organization levels has not been comprehensively characterized. $\mathrm{N}$ and $\mathrm{P}$ concentrations were measured for 329 leaf samples collected at 132 sites along the $5000 \mathrm{~km}$ long China Grassland Transect that traverses the Inner Mongolian and Qinghai-Tibet Plateaus. The patterns of these measurements were analyzed with reference to climate factors, plant species, plant functional groups, grassland communities and grassland ecosystems. The aim was to explore whether geographical patterns of plant leaf elements are related to zonal climatic variables, and at which vegetation organization levels changes of plant leaf $\mathrm{N}$ and $\mathrm{P}$ stoichiometric characteristics and pattern occur. Results showed that interspecific differences of $\mathrm{N}$ and $\mathrm{P}$ concentrations were most significant for the three vegetation organization levels of species, community and ecosystem. Plant leaf $\mathrm{N}$ and $\mathrm{P}$ concentrations were higher, coefficients of variation of $\mathrm{N}$ and $\mathrm{P}$ lower, and $\mathrm{N} / \mathrm{P}, \mathrm{C} / \mathrm{N}$ and $\mathrm{C} / \mathrm{P}$ ratios were also lower for leaf samples from the cold high altitude Qinghai-Tibet Plateau than for those from the relatively lower altitude and warmer Inner Mongolian Plateau. Correlation of $\mathrm{N}$ and $\mathrm{P}$ for Inner Mongolian grassland was higher than that for the Qinghai-Tibet Plateau. The study indicates plant species are the most basic unit influencing plant stoichiometric geographic patterns, and that climatic variables affect leaf element concentrations mainly through their effect on changes of plant species composition of vegetation.
\end{abstract}

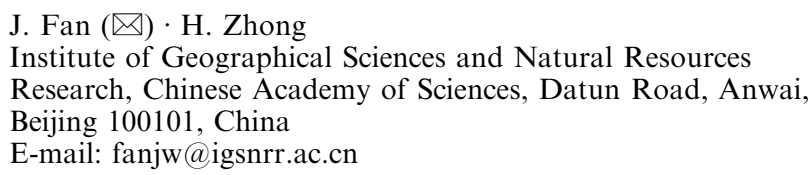

W. Harris

Landcare Research, P.O. Box 69040, Lincoln 7640, New Zealand
Keywords Nitrogen P Phosphorus - Stoichiometry · Climatic variable $\cdot$ Vegetation organization level

\section{Introduction}

$\mathrm{N}$ and $\mathrm{P}$ are generally considered the two most limiting and essential elements for plant growth. Not only do they play a key role in the development of individual plants, they also directly affect plant community composition and physiological activity of plants and determine the structure, function and productivity of ecosystems (Robertson and Vitousek 1981; Vitousek et al. 1989). Through the process of ecosystem nutrient cycles, $\mathrm{N}$ and $\mathrm{P}$ stoichiometry directly affects ecosystem carbon cycling and carbon accumulation. In turn this influences carbon sink capacity of ecosystems and their response to climate change (Giardina and Ryan 2000; Hobbie et al. 2002).

The main driving factors causing changes of plant leaf $\mathrm{N}$ and $\mathrm{P}$ element stoichiometry in bio-geographic pattern and zonal characteristics have been a concern of several studies (Güsewell 2004; Reich and Oleksyn 2004). Both global scale studies (Reich and Oleksyn 2004), and Chinese regional scale studies (Zheng and Shangguan 2006; Ren et al. 2007), have shown good correlation between leaf stoichiometry geographic patterns and climate factors. However, He et al. (2006, 2008) found that climatic variation had very limited influence on changes of element concentrations of plant leaves. Instead, they found that plant interspecific variation and geographic variation were the major factors contributing to stoichiometric changes at the biome level.

Research has shown that element concentrations of plant leaves are distinct for different types of plants, and especially for different plant life forms (Hobbie and Gough 2002; Han et al. 2005). Many studies have suggested that geographical patterns of plant $\mathrm{C}, \mathrm{N}$ and $\mathrm{P}$ 
concentrations are formed because of zonal changes of plant species composition (Reich and Oleksyn 2004; He et al. 2006, 2008). This raises the possibility that climate change could influence plant chemometric characteristics of $\mathrm{C} / \mathrm{N}, \mathrm{C} / \mathrm{P}$ and $\mathrm{N} / \mathrm{P}$ ratios by changing community plant species composition and consequently have significant effects on the carbon cycle of ecological systems.

Several hypotheses have been proposed to explain the formation mechanisms of plant element stoichiometry. Reich and Oleksyn (2004) defined and considered the temperature-plant physiological hypothesis (TPPH), the biogeochemical hypothesis $(\mathrm{BH})$, the species composition hypothesis, and the soil substrate age hypothesis. Of these hypotheses, TPPH has been the one most frequently supported by studies e.g., Reich and Oleksyn 2004; Zheng and Shangguan 2006; Ren et al. 2007. TPPH considers that plant $\mathrm{N}$ and $\mathrm{P}$ concentrations should increase monotonically with decreasing temperature, because plants need to increase leaf element contents to offset reductions of photosynthetic rates under low temperatures.

Although there have been studies on leaf $\mathrm{N}$ and $\mathrm{P}$ concentrations and their proportions for plants related to zonal climate conditions and to different life forms, the mechanisms and consequences of these responses on geographic plant stoichiometric patterns have received little attention. There are various scientific questions to be considered. These include whether geographical pat- terns of plant leaf elements are related to zonal climatic variables and at what vegetation organization level (e.g., species, functional groups, communities, or ecosystems) changes of plant leaf $\mathrm{N}$ and $\mathrm{P}$ stoichiometric characteristics and pattern occur. To consider these questions, we used data from the $5000 \mathrm{~km}$ long China Grassland Transect (CGT) to describe stoichiometric patterns of $\mathrm{N}$ and $\mathrm{P}$ changes for grasslands of the Inner Mongolian and the Qinghai-Tibet Plateaus. From the patterns revealed we endeavor to initiate discussion and advance understanding of the mechanisms and changes of plant element stoichiometry.

\section{Methods}

\section{Research area}

The study was based on data obtained from the CGT located in China's most important grassland region. This traverses the Inner Mongolian and Qinghai-Tibet Plateaus extending through the provinces of Inner Mongolia, Gansu, Qinghai and Tibet (Han et al. 2006; $\mathrm{Hu}$ et al. 2007, 2010; Fan et al. 2008, 2009). Approximately $5000 \mathrm{~km}$ long, the transect lies in a northeast to southwest direction from Hailar, Inner Mongolia $\left(49^{\circ} 15^{\prime} \mathrm{N}, 119^{\circ} 15^{\prime} \mathrm{E}\right)$ in the east to Pulan (Burang Xian), Tibet $\left(30^{\circ} 15^{\prime} \mathrm{N}, 81^{\circ} 10^{\prime} \mathrm{E}\right)$ in the west (Fig. 1). The CGT

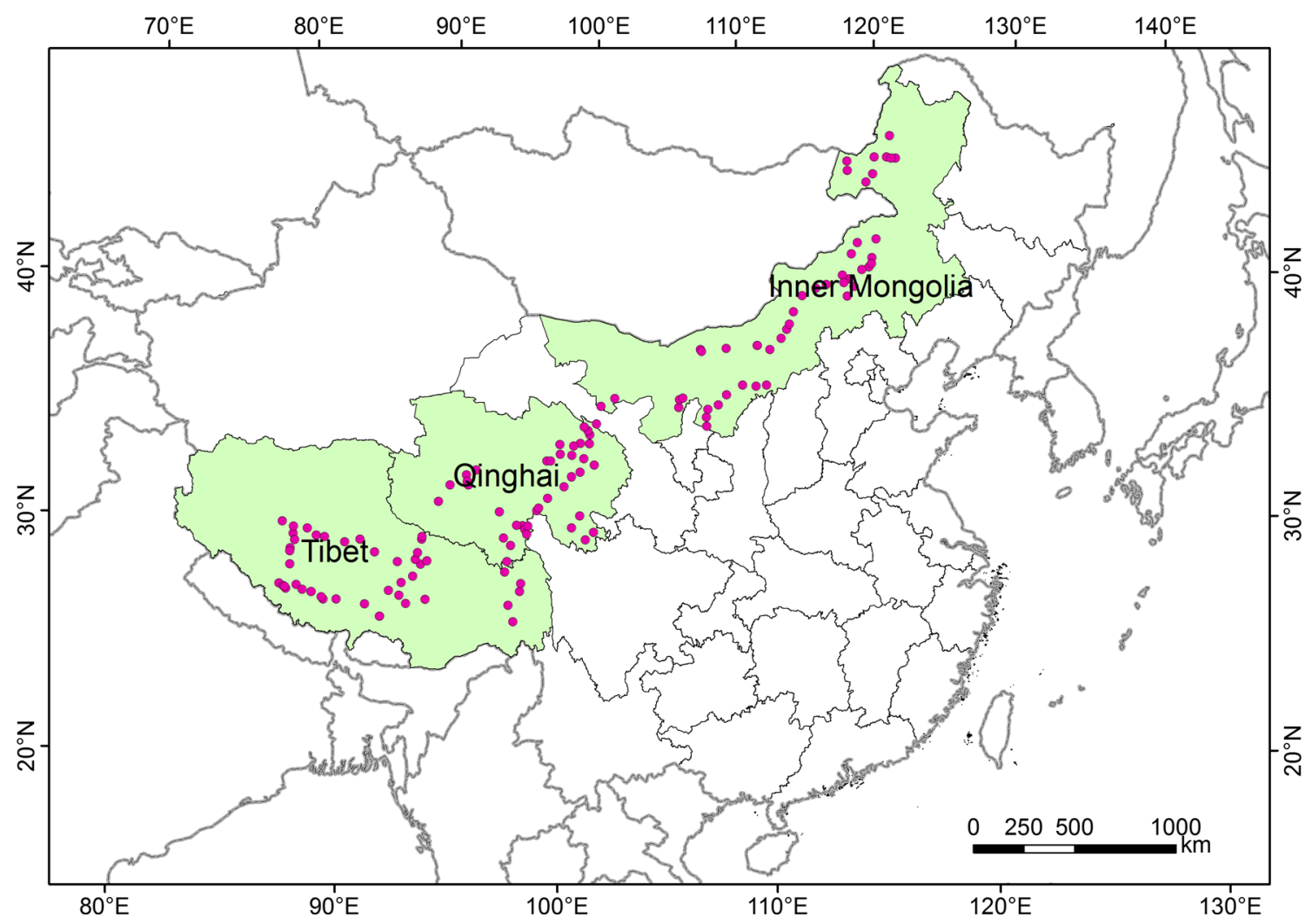

Fig. 1 Location of sample sites along the China Grassland Transect traversing the Inner Mongolian and Qinghai-Tibet Plateaus, China 
encompasses well defined climatic gradients, and includes horizontal and vertical zonal distribution of grassland vegetation.

The Inner Mongolian Plateau has an average elevation of about $1000 \mathrm{~m}$. The Plateau's climate has a transition from semi-humid temperate monsoon in the east to inland arid and semi-arid climates in the west. Mean annual temperature varies from 0 to $8^{\circ} \mathrm{C}$ and mean annual precipitation declines from about $400 \mathrm{~mm}$ in the northeast to less than $50 \mathrm{~mm}$ in the southwest. Generally, soils are steppe soils often with a calcic horizon in the profile. From east to west soil types grade from phaeozem, chernozem, castanozem, brown calcic soil, desert calcic soil, to grey-brown desert soil. There are some intrazonal soils such as meadow soil and aeolian sandy soil. Grassland types change horizontally in relation to the precipitation gradient in the order temperate meadow steppe, temperate steppe, temperate desert steppe, temperate steppe-desert to temperate desert. Dominant species for temperate meadow steppe include Leymus chinensis, Stipa baicalensis, Cleistogenes polyphylla, and Filifolium sibiricum; for temperate steppe Leymus chinensis, Stipa grandis, S. krylovii, Artemisia frigida, Agropyron cristatum, and Cleistogenes squarrosa; for temperate desert steppe Stipa klemenzii, S. breviflora, $S$. gobica, and Cleistogenes songorica; for temperate steppe-desert Salsola passerine, Stipa glareosa, and Caragana sinica; and for temperate desert Ceratoides latens, Haloxylon erinaceum, Reaumurica soongorica, and Nitraria tangutorum (DAHV 1996; CISNR 1996).

The Qinghai-Tibet Plateau has an average elevation of $4000-5000 \mathrm{~m}$. Its climatic characteristics are high radiation, low temperature, large daily temperature differences and large variations in precipitation. In flat areas of the Plateau mean annual temperature is below $0{ }^{\circ} \mathrm{C}$, and the largest diurnal fluctuation of temperature reaches $22{ }^{\circ} \mathrm{C}$. Precipitation varies from above $1000 \mathrm{~mm}$ in the southeast to below $100 \mathrm{~mm}$ in the northwest. Grassland types change in relation to altitude gradient in the order alpine meadow, alpine meadow steppe, alpine steppe, alpine desert steppe, to alpine desert. The dominant species for alpine meadow include Kobresia pygmaea, K. humilis, $K$. capillifolia, and Polygonum viviparum; for alpine meadow steppe Stipa capillacea, $S$. purpurea, and Carex angustifructus; for alpine steppe Stipa purpurea, Carex moorcroftii, and Artemisia wellbyi; for alpine desert steppe Stipa purpurea, S. glareosa, S. caucasica; and for alpine desert Ceratoides campacta, and Ajania tibetica (DAHV 1996; CISNR 1996).

\section{Sample collection and element analysis}

Plant samples were obtained from 132 sites along the CGT at intervals of about $50 \mathrm{~km}$. Collection of leaf samples and measurements of plant biomass were made from 2003-2007 during August to September when most dominant species were at the late flowering stage or fruiting. Two to three dominant species were defined for each site according to plant biomass, abundance and coverage. Mature fresh leaves of ten individuals of each species were collected, placed in paper envelopes, and dried in the sun. A total of 329 leaf samples belonging to 138 species were collected.

Leaf samples were oven-dried for $24 \mathrm{~h}$ and then milled into powder for element analysis. $\mathrm{C}$ and $\mathrm{N}$ concentrations were measured using an isotope mass spectrometer (Thermo, MAT253). P concentration was measured by Optima Inductively Coupled Plasma-Optical Emission Spectrometry (PerkinElmer, Optima 5300DV)after $\mathrm{H}_{2} \mathrm{SO}_{4}-\mathrm{HClO}_{4}$ digestion.

Climate data for mean annual temperature (MAT), mean annual precipitation (MAP), growing season temperature (GST), growing season precipitation (GSP), vapor pressure deficit (VPD) and the aridity index for the sample sites were obtained from the China Climate Grid Database $(1 \times 1 \mathrm{~km})$ constructed by the Chinese Ecosystem Research Network (CERN), of the Chinese Academy of Sciences (CAS). The database was produced by spatial interpolation of values in ANUSPLIN using observation data from 722 weather stations throughout China recorded from 1971 to 2004, and geographical data.

\section{Data analysis}

The means, standard deviations and coefficients of variation $(\mathrm{CV})$ of leaf $\mathrm{C}, \mathrm{N}$ and $\mathrm{P}$ concentrations and their ratios were calculated on a mass basis for the Whole Transect, regions (Inner Mongolia and QinghaiTibet), and plant functional groups (plant family and life form).

The relationship between leaf elements and climate factors (MAT, MAP, GST, GSP, VPD and aridity index) were analyzed using regression analysis. As influences of MAT and MAP on plant elements were more obvious than those of other climate factors, MAT and MAP were used for analysis in the study.

General linear models (GLM) and F tests were used for ANOVA using the R statistical software package. The full model included terms for plant family, species, life form, MAT and MAP. The significance of effects was tested with the $\mathrm{F}$ ratios between mean squares of effects and residuals (He et al. 2006, 2008).

The significance of differences between leaf element concentrations and between ratios were analyzed and compared among plant species (inter-species), plant functional groups (inter-groups), grassland communities (inter-communities), and grassland ecosystems (intergrassland types), and between the two regions.

Grasses, legumes, sedges and other species were separated into plant family groups, and herbs and shrubs were separated as life forms. The 132 sample sites were classified into 66 grassland communities and 10 grassland ecosystems (grassland types) according to the 
China grassland vegetation classification system (DAHV 1996). Grassland communities and grassland types were defined using the Atlas of Grassland Resources of China (CISNR 1996).

\section{Results}

\section{Basic characteristics of plant leaf $\mathrm{C}, \mathrm{N}$ and $\mathrm{P}$}

Table 1 shows the basic characteristics of plant leaf nutrients in the GCT observations. The coefficients of variation $(\mathrm{CV})$ of leaf $\mathrm{P}$ concentrations were highest, those of $\mathrm{N}$ concentrations intermediate, and $\mathrm{C}$ concentrations lowest. For the element ratios, $\mathrm{CV}$ of $\mathrm{C} / \mathrm{P}$ was highest and N/P lowest. For the regions, CVs of leaf $\mathrm{C}$, $\mathrm{N}$ and $\mathrm{P}$ concentrations and $\mathrm{C} / \mathrm{N}$ and $\mathrm{C} / \mathrm{P}$ ratios for Qinghai-Tibet were clearly lower than those for Inner Mongolia.

Apart from $\mathrm{C}$, leaf element concentrations and ratios for the regions were significantly different. Leaf $\mathrm{N}$ and $\mathrm{P}$ concentrations for Qinghai-Tibet were significantly higher, and $\mathrm{C} / \mathrm{N}, \mathrm{N} / \mathrm{P}$ and $\mathrm{C} / \mathrm{P}$ lower than those for Inner Mongolia (Table 1).

Considered for all samples, correlations between leaf $\mathrm{C}$ with $\mathrm{N}$ and $\mathrm{P}$ concentrations were not significant but $\mathrm{N}$ and $\mathrm{P}$ were significantly correlated. The significances of these relationships were stronger for Inner Mongolia than for Qinghai-Tibet (Table 2).
Relationships between leaf N, P and climate factors

For the Whole Transect, leaf $\mathrm{N}$ concentration decreased with increasing MAT $(R=0.119, P<0.05)$, but $\mathrm{P}$ and $\mathrm{N} / \mathrm{P}$ did not change significantly. With increasing MAP, $\mathrm{N} \quad(R=0.213, \quad P<0.001)$ and $\mathrm{P} \quad(R=0.123$, $P<0.05$ ) had a slight increasing trend (Fig. 2). For the regions, only the relationship of increasing $\mathrm{N}$ with increasing MAP in Qinghai-Tibet was obvious.

GLM analyses are summarized in Table 3. MAT and MAP had little direct influence on leaf N, P and $\mathrm{N} / \mathrm{P}$ ratios, together explaining less than 5,3 and $0.2 \%$ of variation in leaf $\mathrm{N}, \mathrm{P}$ and $\mathrm{N} / \mathrm{P}$ ratios respectively. However, species explained 34.4, 45.6 and $41.7 \%$ of the total variation in leaf $\mathrm{N}, \mathrm{P}$ and $\mathrm{N} / \mathrm{P}$ ratios. The interactions of relevant parameters were not significant.

Characteristics of leaf elements for vegetation organization levels

For $\mathrm{N}$ and $\mathrm{P}$ concentrations of the Whole Transect, differences of inter-species and inter-community comparisons were highly significant, whereas the significance level of difference between ecosystems was low. For N and $\mathrm{P}$ concentrations of both regions the significance of difference of inter-species was higher than for intercommunities and inter-ecosystems (Table 4).

Table 1 Means, standard deviations (SD) and coefficients of variation (CV) of regional leaf element concentrations and ratios of grasslands of the China Grassland Transect traversing the Inner Mongolian and Qinghai-Tibet Plateaus

\begin{tabular}{|c|c|c|c|c|c|c|c|c|c|c|c|c|c|}
\hline \multirow{2}{*}{$\begin{array}{l}\text { Element concentrations } \\
\text { and ratios }\end{array}$} & \multicolumn{4}{|c|}{ Whole transect } & \multicolumn{4}{|c|}{ Inner Mongolia } & \multicolumn{4}{|c|}{ Qinghai-Tibet } & \multirow{2}{*}{$\begin{array}{l}P \text { between } \\
\text { region }\end{array}$} \\
\hline & $\mathrm{n}$ & Mean & SD & CV $(\%)$ & $\mathrm{n}$ & Mean & SD & CV $(\%)$ & $\mathrm{n}$ & Mean & SD & CV $(\%)$ & \\
\hline $\mathrm{C}\left(\mathrm{mg} \mathrm{g}^{-1}\right)$ & 329 & 463.76 & 41.84 & 9.02 & 90 & 460.83 & 51.87 & 11.26 & 239 & 464.86 & 37.44 & 8.05 & ns \\
\hline $\mathrm{N}\left(\mathrm{mg} \mathrm{g}^{-1}\right)$ & 329 & 19.94 & 6.84 & 34.30 & 90 & 17.02 & 7.75 & 45.53 & 239 & 21.04 & 6.14 & 29.18 & $* * *$ \\
\hline $\mathrm{P}\left(\mathrm{mg} \mathrm{g}^{-1}\right)$ & 326 & 1.35 & 0.68 & 50.37 & 89 & 1.11 & 0.85 & 76.55 & 237 & 1.45 & 0.59 & 40.46 & $* * *$ \\
\hline $\mathrm{C} / \mathrm{N}$ & 329 & 26.86 & 12.80 & 47.65 & 90 & 33.93 & 18.03 & 53.15 & 239 & 24.19 & 8.84 & 36.53 & $* * *$ \\
\hline $\mathrm{N} / \mathrm{P}$ & 326 & 16.59 & 6.46 & 38.94 & 89 & 17.90 & 6.39 & 35.67 & 237 & 16.10 & 6.43 & 39.92 & $*$ \\
\hline $\mathrm{C} / \mathrm{P}$ & 326 & 439.84 & 279.52 & 63.55 & 89 & 611.75 & 418.70 & 68.44 & 237 & 375.28 & 164.00 & 43.70 & $* * *$ \\
\hline
\end{tabular}

$P$ for regions compares Inner Mongolia and Qinghai-Tibet plateaus ns not significant

* $P<0.05, * * P<0.01, * * * P<0.001$

Table 2 Correlations between leaf C, N and P concentrations for the Whole Transect, and the Inner Mongolian and Qinghai-Tibet Plateau regions of the China Grassland transect

\begin{tabular}{|c|c|c|c|c|c|c|c|c|c|}
\hline \multirow[t]{2}{*}{ Element pairs } & \multicolumn{3}{|c|}{ Whole transect } & \multicolumn{3}{|c|}{ Inner Mongolia } & \multicolumn{3}{|c|}{ Qinghai-Tibet } \\
\hline & $\mathrm{n}$ & Pearson correlation & $P$ & $\mathrm{n}$ & Pearson correlation & $P$ & $\mathrm{n}$ & Pearson correlation & $P$ \\
\hline $\mathrm{C}-\mathrm{N}$ & 329 & 0.047 & ns & 90 & -0.051 & ns & 239 & 0.094 & $\mathrm{~ns}$ \\
\hline C-P & 326 & -0.039 & ns & 89 & -0.068 & $\mathrm{~ns}$ & 237 & -0.037 & ns \\
\hline N-P & 326 & 0.593 & $* * *$ & 89 & 0.686 & $* * *$ & 237 & 0.491 & $* * *$ \\
\hline
\end{tabular}

$n s$ not significant

* $P<0.05$; ** $P<0.01$; *** $P<0.001$ 


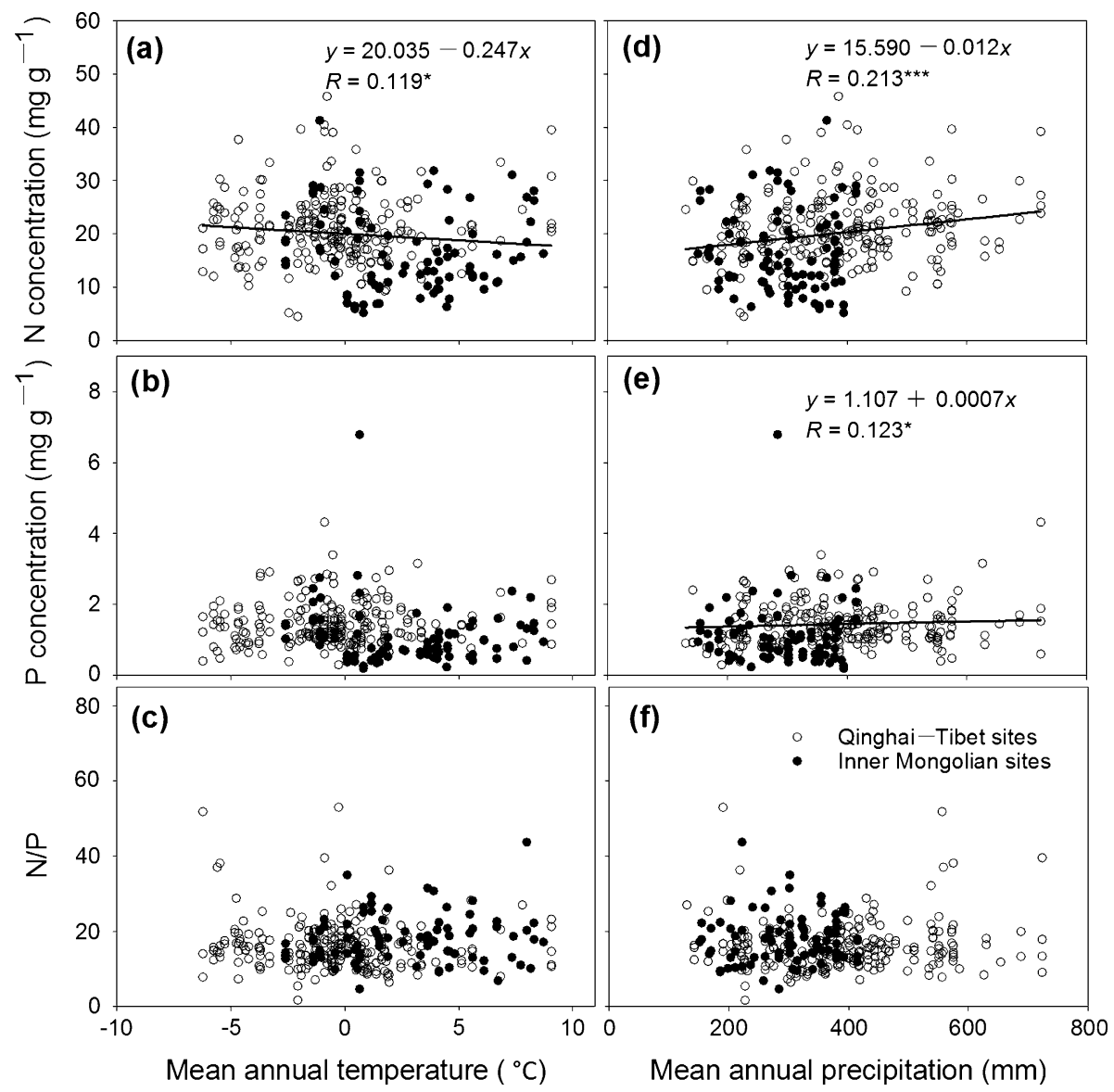

Fig. 2 a-f Relationships between grassland leaf N, P concentrations and N/P ratios and mean annual temperature (MAT, a-c) and mean annual precipitation (MAP, $\mathbf{d}-\mathbf{f}$ ), where relationships are significant, the regression formulae are given and linear regressions are plotted

Table 3 Summary of the general linear models for the effect of mean annual temperature (MAT), mean annual precipitation (MAP), plant family group (Family), life form (LF) and Species on leaf N, P and N/P

\begin{tabular}{|c|c|c|c|c|c|c|c|c|c|c|c|c|c|}
\hline \multirow[t]{2}{*}{ Terms } & \multicolumn{5}{|l|}{$\mathrm{N}$} & \multicolumn{4}{|l|}{$\mathrm{P}$} & \multicolumn{4}{|l|}{$\mathrm{N} / \mathrm{P}$} \\
\hline & df & MS & $F$ & $P$ & SS \% & MS & $F$ & $P$ & SS $\%$ & MS & $F$ & $P$ & SS $\%$ \\
\hline \multicolumn{14}{|c|}{ MAT entered first } \\
\hline MAT & 1 & 0.829 & 9.313 & 0.003 & 1.69 & 0.254 & 5.617 & 0.019 & 1.02 & 0.012 & 0.094 & 0.760 & 0.03 \\
\hline MAP & 1 & 1.301 & 14.612 & 0.000 & 2.65 & 0.313 & 6.940 & 0.009 & 1.26 & 0.034 & 0.273 & 0.602 & 0.07 \\
\hline \multicolumn{14}{|c|}{ MAP entered first } \\
\hline MAP & 1 & 1.892 & 21.243 & 0.000 & 3.86 & 0.481 & 10.650 & 0.001 & 1.93 & 0.020 & 0.164 & 0.686 & 0.04 \\
\hline MAT & 1 & 0.239 & 2.682 & 0.103 & 0.49 & 0.086 & 1.907 & 0.169 & 0.35 & 0.025 & 0.203 & 0.653 & 0.06 \\
\hline \multicolumn{14}{|l|}{ Other terms } \\
\hline Family & 3 & 3.692 & 41.459 & 0.000 & 22.58 & 1.027 & 22.733 & 0.000 & 12.38 & 0.407 & 3.283 & 0.022 & 2.69 \\
\hline $\mathrm{LF}$ & 1 & 0.001 & 0.015 & 0.904 & 0.00 & 0.774 & 17.137 & 0.000 & 3.11 & 1.702 & 13.743 & 0.000 & 3.76 \\
\hline Species & 133 & 0.127 & 1.425 & 0.013 & 34.41 & 0.085 & 1.890 & 0.000 & 45.64 & 0.142 & 1.147 & 0.193 & 41.68 \\
\hline Residuals & 189 & 0.089 & & & 34.32 & 0.045 & & & 34.31 & 0.124 & & & 51.67 \\
\hline
\end{tabular}

Leaf traits were log-10 transformed prior to analysis

$M S$ mean sum of square. $S S \%$ percentage of sum of squares explained

Leaf $\mathrm{N}$ and $\mathrm{P}$ characteristics of plant functional groups

Table 5 shows the basic profiles of leaf elements for plant families. For the Whole Transect, $\mathrm{N}$ and $\mathrm{P}$ concentrations of grasses were markedly lower than those of other families and were particularly high for legumes. Legumes had significantly higher $\mathrm{N} / \mathrm{P}$ ratio than the other families for the Whole Transect and for Inner Mongolia but not for Qinghai-Tibet.

$\mathrm{N}$ and $\mathrm{P}$ concentrations of legumes and grasses for Qinghai-Tibet were clearly higher but their N/P ratios were lower for Inner Mongolia. Regional differences for sedges and other families were not significant. Coefficients of variation of leaf $\mathrm{N}$ and $\mathrm{P}$ concentrations of 
Table 4 Significance levels $(P)$ of leaf element differences of inter-species, inter-communities, and inter-ecosystems comparisons for the Whole China Grassland Transect and for the Inner Mongolian and Qinghai-Tibet Plateaus

\begin{tabular}{|c|c|c|c|c|c|c|c|c|c|}
\hline \multirow[t]{2}{*}{ Vegetation levels comparison } & \multicolumn{3}{|c|}{ Whole transect } & \multicolumn{3}{|c|}{ Inner Mongolia } & \multicolumn{3}{|c|}{ Qinghai -Tibet } \\
\hline & $\mathrm{N}$ & $\mathrm{P}$ & $\mathrm{N} / \mathrm{P}$ & $\mathrm{N}$ & $\mathrm{P}$ & $\mathrm{N} / \mathrm{P}$ & $\mathrm{N}$ & $\mathrm{P}$ & $\mathrm{N} / \mathrm{P}$ \\
\hline Number of samples & 328 & 325 & 325 & 89 & 88 & 88 & 238 & 236 & 236 \\
\hline Inter-species & $* * *$ & $* * *$ & ns & $* * *$ & $* * *$ & $* * *$ & $* * *$ & $* *$ & ns \\
\hline Inter-communities & $* * *$ & $* * *$ & ** & ns & $* *$ & $* *$ & $*$ & ns & ns \\
\hline Inter-ecosystems & $*$ & $*$ & $*$ & ns & ns & ns & ns & ns & $*$ \\
\hline
\end{tabular}

ns not significant

$* P<0.05, * * P<0.01, * * * P<0.001$

Table 5 Means, standard deviations (SD) and coefficients of variation $(\mathrm{CV})$ of leaf $\mathrm{N}$ and $\mathrm{P}$ concentrations and the N/P ratios for legumes, grasses, sedges and other families for the Whole transect and for the Inner Mongolian and Qinghai-Tibet Plateaus

\begin{tabular}{|c|c|c|c|c|c|c|c|c|c|c|c|c|c|c|}
\hline \multirow[t]{2}{*}{ Plant family } & \multirow{2}{*}{$\begin{array}{l}\text { Element concentrations } \\
\text { and ratios }\end{array}$} & \multicolumn{4}{|c|}{ Whole transect } & \multicolumn{4}{|c|}{ Inner Mongolia } & \multicolumn{4}{|c|}{ Qinghai-Tibet } & \multirow{2}{*}{$\begin{array}{l}P \text { between } \\
\text { regions }\end{array}$} \\
\hline & & $\mathrm{n}$ & Mean & $\mathrm{SD}$ & CV $(\%)$ & $\mathrm{n}$ & Mean & SD & CV $(\%)$ & $\mathrm{n}$ & Mean & SD & $\mathrm{CV}(\%)$ & \\
\hline \multirow[t]{3}{*}{ Grasses } & $\mathrm{N}\left(\mathrm{mg} \mathrm{g}^{-1}\right)$ & 113 & 15.75 & 5.23 & 33.21 & 53 & 13.79 & 6.33 & 45.90 & 62 & 17.43 & 3.29 & 18.88 & $* * *$ \\
\hline & $\mathrm{P}\left(\mathrm{mg} \mathrm{g}^{-1}\right)$ & 113 & 1.05 & 0.49 & 46.67 & 53 & 0.85 & 0.51 & 60.00 & 62 & 1.22 & 0.41 & 33.61 & $* * *$ \\
\hline & $\mathrm{N} / \mathrm{P}$ & 113 & 16.58 & 5.24 & 31.63 & 53 & 17.93 & 5.12 & 28.56 & 62 & 15.42 & 5.11 & 33.14 & $* *$ \\
\hline \multirow[t]{3}{*}{ Sedges } & $\mathrm{N}\left(\mathrm{mg} \mathrm{g}^{-1}\right)$ & 94 & 20.49 & 4.24 & 20.69 & 4 & 25.02 & 4.40 & 17.59 & 90 & 20.28 & 4.14 & 20.41 & $*$ \\
\hline & $\mathrm{P}\left(\mathrm{mg} \mathrm{g}^{-1}\right)$ & 94 & 1.40 & 0.49 & 35.00 & 4 & 1.67 & 0.42 & 25.15 & 90 & 1.39 & 0.50 & 35.97 & ns \\
\hline & $\mathrm{N} / \mathrm{P}$ & 94 & 16.20 & 6.52 & 40.28 & 4 & 15.30 & 1.94 & 12.68 & 90 & 16.24 & 6.66 & 41.01 & ns \\
\hline \multirow[t]{3}{*}{ Legumes } & $\mathrm{N}\left(\mathrm{mg} \mathrm{g}^{-1}\right)$ & 22 & 29.51 & 7.77 & 26.33 & 8 & 24.42 & 6.11 & 25.02 & 14 & 32.42 & 7.23 & 22.30 & $*$ \\
\hline & $\mathrm{P}\left(\mathrm{mg} \mathrm{g}^{-1}\right)$ & 22 & 1.7 & 0.83 & 48.82 & 8 & 1.03 & 0.62 & 60.19 & 14 & 2.08 & 0.68 & 32.69 & $* *$ \\
\hline & $\mathrm{N} / \mathrm{P}$ & 22 & 20.67 & 8.65 & 41.84 & 8 & 27.77 & 9.69 & 34.89 & 14 & 16.62 & 4.64 & 27.92 & $* * *$ \\
\hline \multirow[t]{3}{*}{ Others } & $\mathrm{N}\left(\mathrm{mg} \mathrm{g}^{-1}\right)$ & 97 & 22.17 & 7.00 & 31.57 & 25 & 20.21 & 7.74 & 38.30 & 73 & 22.84 & 6.66 & 29.16 & ns \\
\hline & $\mathrm{P}\left(\mathrm{mg} \mathrm{g}^{-1}\right)$ & 97 & 1.58 & 0.85 & 53.80 & 25 & 1.57 & 1.24 & 78.98 & 73 & 1.59 & 0.66 & 41.51 & ns \\
\hline & $\mathrm{N} / \mathrm{P}$ & 97 & 16.07 & 6.87 & 42.76 & 25 & 15.10 & 4.91 & 32.52 & 73 & 16.40 & 7.43 & 45.30 & ns \\
\hline \multirow[t]{3}{*}{$P$ between families } & $\mathrm{N}$ & & $* * *$ & & & & $* * *$ & & & & $* * *$ & & & \\
\hline & $\mathrm{P}$ & & $* * *$ & & & & $* * *$ & & & & $* * *$ & & & \\
\hline & $\mathrm{N} / \mathrm{P}$ & & $*$ & & & & $* * *$ & & & & ns & & & \\
\hline
\end{tabular}

$n s$ not significant

* $P<0.05$, ** $P<0.01$, *** $P<0.001$

grasses and legumes for Qinghai-Tibet were less than those for Inner Mongolia, but for sedges the regional difference was the reverse. Coefficients of variation of $\mathrm{N} / \mathrm{P}$ ratio of grasses, sedges and other families for Qinghai-Tibet were higher than those for Inner Mongolia, whereas legumes had higher CV for Inner Mongolia.

For the Whole Transect, correlations between $\mathrm{N}$ and $\mathrm{P}$ for grasses and legumes were strongest and those of sedges weakest. The correlations were also significant for grasses for the two regions but not for legumes (Table 6).

Table 7 shows the basic profiles of leaf elements for plant life form. $\mathrm{N}$ concentration and the $\mathrm{N} / \mathrm{P}$ ratio of herbs were slightly lower than those of shrubs for the Whole Transect. Herb $\mathrm{N}$ and $\mathrm{P}$ concentrations were higher for Qinghai-Tibet than for Inner Mongolia, but the herb N/P ratio for Qinghai-Tibet was lower than for Inner Mongolia. Differences of shrub leaf N, P and N/P ratio between regions were not significant. The correlation between $\mathrm{N}$ and $\mathrm{P}$ was significant for both herbs $(R=0.624, \quad P<0.001)$ and shrubs $(R=0.406$, $P<0.01)$.

\section{Discussion}

The basic characteristics of element stoichiometry

The $\mathrm{CV}$ of leaf $\mathrm{P}$ was higher than that for $\mathrm{N}$ and $\mathrm{C}$ indicating the greater variability of $\mathrm{P}$ concentration. The strong positive correlation between $\mathrm{N}$ and $\mathrm{P}$ and the absence of correlations between $\mathrm{C}$ and $\mathrm{N}$ and between $\mathrm{C}$ and $\mathrm{P}$, have been found in many other studies (Thompson et al. 1997; Reich and Oleksyn 2004; Han et al. 2005; Zheng and Shangguan 2006). We observed differences in the strength of the correlation between $\mathrm{N}$ and $\mathrm{P}$ for different plant families. The correlations of $\mathrm{N}$ and $\mathrm{P}$ for grasses and legumes were higher than that for sedges and these correlations were stronger for Inner Mongolia than for Qinghai-Tibet (Tables 2, 6). This may be because grass and legume species are more common in Inner Mongolian than in Qinghai-Tibet grasslands (DAHV 1996).

$\mathrm{N} / \mathrm{P}$ ratio is an important index in the description of community vegetation structure, function and nutrient limitation (Koerselman and Meuleman 1996; Thompson 
Table 6 Correlations of leaf $\mathrm{N}$ and $\mathrm{P}$ concentrations for grasses, legumes, sedges and other families for the Whole Transect and the Inner Mongolian and Qinghai-Tibet Plateaus

\begin{tabular}{|c|c|c|c|c|c|c|c|c|c|}
\hline \multirow[t]{2}{*}{ Plant family } & \multicolumn{3}{|c|}{ Whole transect } & \multicolumn{3}{|c|}{ Inner Mongolia } & \multicolumn{3}{|c|}{ Qinghai-Tibet } \\
\hline & $\mathrm{n}$ & Pearson correlation & $P$ & $\mathrm{n}$ & Pearson correlation & $P$ & $\mathrm{n}$ & Pearson correlation & $P$ \\
\hline Grasses & 113 & 0.694 & $* * *$ & 52 & 0.826 & $* * *$ & 61 & 0.330 & $* *$ \\
\hline Legumes & 22 & 0.653 & $* * *$ & 8 & 0.679 & ns & 14 & 0.426 & ns \\
\hline Sedges & 94 & 0.288 & $* *$ & 4 & 0.846 & ns & 90 & 0.255 & $*$ \\
\hline Others & 97 & 0.506 & $* * *$ & 25 & 0.634 & $* * *$ & 72 & 0.447 & $* * *$ \\
\hline
\end{tabular}

ns not significant

$* P<0.05, * * P<0.01, * * * P<0.001$

Table 7 Means, standard deviations (SD) and coefficients of variation (CV) of leaf $\mathrm{N}$ and $\mathrm{P}$ concentrations and the N/P ratios of herb and shrub species for the Whole Transect and for the Inner Mongolian and Qinghai-Tibet Plateaus

\begin{tabular}{|c|c|c|c|c|c|c|c|c|c|c|c|c|c|c|}
\hline \multirow[t]{2}{*}{ Life form } & \multirow{2}{*}{$\begin{array}{l}\text { Element concentrations } \\
\text { and ratios }\end{array}$} & \multicolumn{4}{|c|}{ Whole transect } & \multicolumn{4}{|c|}{ Inner Mongolia } & \multicolumn{4}{|c|}{ Qinghai-Tibet } & \multirow{2}{*}{$\begin{array}{l}P \text { between } \\
\text { regions }\end{array}$} \\
\hline & & $\mathrm{n}$ & Mean & SD & $\mathrm{CV}(\%)$ & $\mathrm{n}$ & Mean & SD & $\mathrm{CV}(\%)$ & $\mathrm{n}$ & Mean & $\mathrm{SD}$ & $\mathrm{CV}(\%)$ & \\
\hline \multirow[t]{3}{*}{ Herb } & $\mathrm{N}\left(\mathrm{mg} \mathrm{g}^{-1}\right)$ & 289 & 19.62 & 6.86 & 34.96 & 75 & 16.10 & 7.54 & 46.83 & 214 & 20.86 & 6.16 & 29.53 & $* * *$ \\
\hline & $\mathrm{P}\left(\mathrm{mg} \mathrm{g}^{-1}\right)$ & 287 & 1.36 & 0.70 & 51.47 & 74 & 1.07 & 0.87 & 81.31 & 213 & 1.47 & 0.60 & 40.82 & $* * *$ \\
\hline & $\mathrm{N} / \mathrm{P}$ & 289 & 16.19 & 6.11 & 37.74 & 75 & 17.51 & 5.42 & 30.95 & 214 & 15.73 & 6.28 & 39.92 & $*$ \\
\hline \multirow[t]{3}{*}{ Shrub } & $\mathrm{N}\left(\mathrm{mg} \mathrm{g}^{-1}\right)$ & 39 & 22.19 & 6.37 & 28.71 & 15 & 21.61 & 7.34 & 33.97 & 25 & 22.53 & 5.85 & 25.97 & ns \\
\hline & $\mathrm{P}\left(\mathrm{mg} \mathrm{g}^{-1}\right)$ & 39 & 1.27 & 0.52 & 40.94 & 15 & 1.31 & 0.72 & 54.96 & 24 & 1.25 & 0.361 & 28.88 & ns \\
\hline & $\mathrm{N} / \mathrm{P}$ & 39 & 19.54 & 8.07 & 41.30 & 15 & 19.83 & 9.92 & 50.03 & 25 & 19.36 & 6.89 & 35.59 & ns \\
\hline \multirow[t]{3}{*}{$P$ between groups } & $\mathrm{N}$ & & $*$ & & & & $*$ & & & & ns & & & \\
\hline & $\mathrm{P}$ & & ns & & & & ns & & & & ns & & & \\
\hline & $\mathrm{N} / \mathrm{P}$ & & $* *$ & & & & ns & & & & $* *$ & & & \\
\hline
\end{tabular}

ns not significant

$* P<0.05, * * P<0.01, * * * P<0.001$

Table 8 Comparison of leaf $\mathrm{N}$ and $\mathrm{P}$ concentrations and the N/P ratios of the China Grassland Transect and global vegetation

\begin{tabular}{|c|c|c|c|c|c|c|}
\hline \multirow[t]{2}{*}{ Studies } & \multicolumn{2}{|c|}{$\mathrm{N}\left(\mathrm{mg} \mathrm{g}^{-1}\right)$} & \multicolumn{2}{|c|}{$\mathrm{P}\left(\mathrm{mg} \mathrm{g}^{-1}\right)$} & \multicolumn{2}{|l|}{$\mathrm{N} / \mathrm{P}$} \\
\hline & $\mathrm{n}$ & Mean & $\mathrm{n}$ & Mean & $\mathrm{n}$ & Mean \\
\hline This study & 329 & 19.94 & 326 & 1.35 & 326 & 16.59 \\
\hline Global vegetation (Reich and Oleksyn 2004) & 1251 & 20.09 & 923 & 1.77 & 894 & 13.80 \\
\hline$P$ between studies & & $* *$ & & $* *$ & & $* *$ \\
\hline
\end{tabular}

ns not significant

$* P<0.05, * * P<0.01, * * * P<0.001$

et al. 1997; Güsewell 2004; McGroddy et al. 2004; Reich and Oleksyn 2004; Niklas et al. 2005). Braakhekke and Hooftmann (1999) considered that plants with N/P ratios less than 14 will be restricted by $\mathrm{N}$ availability, whereas plants with $\mathrm{N} / \mathrm{P}$ ratios more than 16 will be restricted by $\mathrm{P}$ availability. Our results show (Table 8 ) that the mean leaf $\mathrm{N} / \mathrm{P}$ ratio (16.6) in the Chinese Grassland Transect was high compared to the global mean of 13.8 (Reich and Oleksyn 2004). Leaf N concentration of Chinese grassland is only $9.5 \%$ lower, but $\mathrm{P}$ concentration is $23.8 \%$ lower than the global vegetation mean. This is a strong indication that Chinese grassland vegetation is universally limited by the availability of P. Soil P concentration in China is lower than the global average (SOSS 1993; Zhang et al. 2005) and this is most likely the main reason for the low $\mathrm{P}$ concentration of the leaves in Chinese grasslands.
Geographic pattern of elements and climatic variation

Our result for the relationship between plant $\mathrm{N}$ concentration and MAT is consistent with previous studies (Reich and Oleksyn 2004; Han et al. 2005; Ren et al. 2007). This gives support to the temperature-plant physiology hypothesis (TPPH), which considers that plant $\mathrm{N}$ and $\mathrm{P}$ concentrations should increase monotonically with decreasing temperature (Reich and Oleksyn 2004). Results for the regions also confirmed that leaf $\mathrm{N}$ and $\mathrm{P}$ concentrations in colder Qinghai-Tibet were respectively 23.6 and $30.6 \%$ higher than those in warmer Inner Mongolia (Table 1).

We also found that plants of different functional groups had different responses to the geographical and climatic factors. For example, leaf $\mathrm{N}$ and $\mathrm{P}$ concentrations of grasses and legumes in Qinghai-Tibet were 
higher and N/P was distinctly lower than those in Inner Mongolia. The differences between the regions for $\mathrm{N}, \mathrm{P}$ and $\mathrm{N} / \mathrm{P}$ of other functional groups were not significant. This may indicate that the characteristic of high $\mathrm{N}$ and $\mathrm{P}$ and low $\mathrm{N} / \mathrm{P}$ in very cold areas is more obvious in particular plant functional groups. Moreover, the lower $\mathrm{CV}$ s of leaf $\mathrm{N}$ and $\mathrm{P}$ for Qinghai-Tibet compared to Inner Mongolia may indicate that variation of plant $\mathrm{N}$ and $\mathrm{P}$ concentrations in cold regions is less than that in warmer regions. Further studies are needed to substantiate these results.

Although there were correlations between leaf elements and temperature or precipitation, the ANOVA indicated that the variation in leaf $\mathrm{N}$. $\mathrm{P}$ and $\mathrm{N} / \mathrm{P}$ explained by variation in MAT was less than that explained by species. This supports the finding of $\mathrm{He}$ et al. (2006, 2008), and provides confirmation that at the biome scale temperature affects leaf $\mathrm{N}$ mainly through change in plant species composition rather than by temperature directly. Meanwhile, $\mathrm{N}$ and $\mathrm{P}$ concentrations and their ratio reflect the adaptation of plants to local soil conditions (Thompson et al. 1997; Güsewell 2004; Reich and Oleksyn 2004). Thus temperature and precipitation may affect leaf elements through their influence on soil nutrient status. It is a reasonable assumption that precipitation is a more important limiting factor than temperature for vegetation growth in arid and semi-arid regions. This makes precipitation more likely to have a greater effect on plant composition and leaf element concentrations than temperature in these regions.

Element differences at the vegetation organization level

We found that inter-species differences of $\mathrm{N}$ and $\mathrm{P}$ concentration and their proportion were well defined. This suggests that changes of plant N, P element concentrations mainly occur at the species level. Consequently, it is concluded that plant species differences are the basic factors influencing geographic stoichiometric pattern. This conclusion is consistent with the GLM analysis and confirms the results of $\mathrm{He}$ et al. $(2006,2008)$ and also our findings on the relative contribution of factors influencing $\mathrm{N}$ and $\mathrm{P}$ concentrations. It also supports the species composition hypothesis of Reich and Oleksyn (2004) that states that changes of plant species composition are the main causes of differences of bio-geographic patterns of leaf $\mathrm{N}$ and $\mathrm{P}$ concentration.

The significance levels of differences of leaf $\mathrm{N}$ and $\mathrm{P}$ concentrations generally decrease from species level to community level and then to ecosystem level. This could be because differences among species are balanced out by the greater number and mixing of plant species in higher vegetation levels. Thus the effects of environment change on stoichiometry at the community and ecosystems levels may be dampened by inertia effects. We consider that in the process of plant evolution, when vegetation was influenced by strong changes of biotic or abiotic factors, the lower species level, and perhaps even the organ level, had larger variation and fluctuations. Thus, for the continuous normal stability of whole systems, higher ecosystem and vegetation levels possess self-regulation that enables these levels to have more stable nutrient status.

\section{Element differences of functional groups}

We found that $\mathrm{N}$ and $\mathrm{P}$ concentrations of grass leaves were much lower than those of other families, and that legumes leaves had the highest $\mathrm{N}$ and $\mathrm{P}$ concentrations and $\mathrm{N} / \mathrm{P}$ ratio (Table 5). Other studies have found leaf nutrient concentrations of grasses to be lower than those of dicotyledonous plants (Thompson et al. 1997; Reich and Oleksyn 2004). There is the obvious likelihood that as legumes fix nitrogen they will have high $\mathrm{N}$ concentrations. They also have the requirement of an adequate supply of $\mathrm{P}$ to support symbiotic $\mathrm{N}$-fixation (hence higher $\mathrm{P}$ concentrations) and overall, they will have a higher $\mathrm{N} / \mathrm{P}$ ratio as they are less limited by $\mathrm{N}$ than species reliant on uptake of soil N. Tilman (1982), in reference to the resource competition scale model, conjectured that species with low concentrations of nutrient elements were more suited for growth in nutrient deficient soils. Thus species with lower $\mathrm{N}$ and $\mathrm{P}$ concentrations should have competitive advantage over other species in N-restricted and/or P-limited environments (Tilman 1997). Therefore, in nutrient deficient soils of the grasslands of northern China, the lower $\mathrm{N}$ and $\mathrm{P}$ concentrations of grasses could give them an advantage in resource competition and lead to their dominance of these grasslands.

Han et al. (2005) found that leaf $\mathrm{N}$ and $\mathrm{P}$ concentrations of herbs are higher than those of shrubs, and those of shrubs are higher than those of trees. The marginally higher $\mathrm{N}$ concentration of shrubs compared to herbs in our research was contrary to this findings. Further, the $\mathrm{P}$ concentration of shrubs and herbs did not differ significantly, and the difference between herbs and shrubs was marginal (Table 7). From the information we have it is not possible to explain the differences between our study and that of Han et al. (2005).

The role of plant species in the element geographical pattern

GLM analysis (Table 3) and ANOVA of leaf elements of the vegetation organization levels (Table 4) show that plant species are the most basic factor affecting stoichiometric biogeographic pattern. Further, Table 5 shows that the differences of leaf elements among plant family groups were significant for the whole transect, and for both the Inner Mongolian and Qinghai Tibet Plateaus. It also confirms the results of Tables 3 and 4. Further, Table 5 shows that between the Inner Mongolian and Qinghai Tibet Plateaus the differences of leaf 
elements of grasses and legumes were significant. However, not all of the plant family groups differences were significant between the two regions. It also indicates that some of the plant family and species changes play a key role in the formation of regional plant stoichiometric pattern, and that climate factors affect plant leaf stoichiometric geographical pattern through changes of plant species composition.

\section{Conclusion}

From our analysis, plant species entities are the most basic units influencing plant stoichiometric geographic patterns, with climatic variables affecting leaf element concentrations mainly through the changes of botanical composition of vegetation caused by them. Compared to the mean value of global vegetation, leaf N/P of Chinese grassland plants is high, which indicates that Chinese grassland vegetation is universally limited by the availability of $\mathrm{P}$. Leaf $\mathrm{N}$ and $\mathrm{P}$ concentrations were higher, coefficients of variation of $\mathrm{N}$ and $\mathrm{P}$ were lower, and $\mathrm{N} / \mathrm{P}$, $\mathrm{C} / \mathrm{N}$ and $\mathrm{C} / \mathrm{P}$ ratios were also lower in the cold high altitude Qinghai-Tibet Plateau than corresponding values for the lower altitude and relatively warmer Inner Mongolian Plateau. It is suggested that partitioning of factors determining patterns of the stoichiometric relationships of $\mathrm{N}$ and $\mathrm{P}$ could be further clarified by inclusion, where data are available, of soil element concentrations of the sites. This follows from the assumption that soil nutrient availability influences plant community species composition. The study contributes to understanding of $\mathrm{C}, \mathrm{N}$ and $\mathrm{P}$ elements cycles and will assist prediction of the influence of their changes on these ecologically fragile regions in response to global climate change.

Acknowledgments The research was funded by the National Natural Science Foundation of China 31070427 and the State Key Technologies R \& D Programme 2013BAC03B04. We are grateful to Wenyan Zhang, Bin Han, Zhongmin Hu, and Lulu Song for helping with field measurements, and anonymous reviewers for their constructive suggestions to improve the paper.

\section{References}

Braakhekke WG, Hooftmann DAP (1999) The resource balance hypothesis of plant species diversity in grassland. J Veg Sci 10:187-200

CISNR (Commission for Integrated Survey of Natural Resources, Chinese Academy of Sciences) (1996) Map of grassland resources in China (1:1 M). Science Press, Beijing (In Chinese)

DAHV (Department of Animal Husbandry and Veterinary, Ministry of Agriculture) (1996) Rangeland resources of China. China Agricultural Science and Technology Press, Beijing (In Chinese)

Fan JW, Zhong HP, Harris W, Yu GR, Wang SQ, Hu ZM, Yue YZ (2008) Carbon storage in the grasslands of China based on field measurements of above- and below-ground biomass. Clim Change 86:375-396
Fan JW, Wang K, Zhong HP, Harris W, Hu ZM, Han B, Zhang WY, Wang JB (2009) Allocation of vegetation biomass across a climate-related gradient in the grasslands of Inner Mongolia. J Arid Environ 73:521-528

Giardina CP, Ryan MG (2000) Biogeochemistry: soil warming and organic carbon content reply. Nature 408:790

Güsewell S (2004) N: P ratios in terrestrial plants: variation and functional significance. New Phytol 164:243-266

Han WX, Fang JY, Guo DL, Zhang Y (2005) Leaf nitrogen and phosphorus stoichiometry across 753 terrestrial species in China. New Phytol 168:377-385

Han B, Fan JW, Zhong HP (2006) Grassland biomasses of communities along gradients of the Inner Mongolia transect. Chin J Plant Ecol 30:553-562 (In Chinese with English abstract)

He JS, Fang JY, Wang ZH, Guo D, Flynn FBD, Geng Z (2006) Stoichiometry and large-scale pattern of leaf carbon and nitrogen in the grassland biomes of China. Oecologia 149:115-122

He JS, Wang L, Flynn FBD, Wang XP, Ma WH, Fang JY (2008) Leaf nitrogen: phosphorus stoichiometry across Chinese grassland biomes. Oecologia 155:301-310

Hobbie SE, Gough L (2002) Foliar and soil nutrients in tundra on glacial landscapes of contrasting ages in northern Alaska. Oecologia 131:453-462

Hobbie SE, Nadelhoffer KJ, Hgberg P (2002) A synthesis: the role of nutrients as constraints on carbon balances in boreal and arctic regions. Plant Soil 242:163-170

$\mathrm{Hu}$ ZM, Fan JW, Zhong HP, Yu GR (2007) Spatiotemporal dynamics of aboveground primary productivity along a precipitation gradient in Chinese temperate grassland. Sci China ser D 50:754-764

Hu ZM, Yu GR, Fan JW, Zhong HP, Wang SQ, Li SG (2010) Precipitation-use efficiency along a $4500-\mathrm{km}$ grassland transect. Glob Ecol Biogeogr 19:842-851

Koerselman W, Meuleman AFM (1996) The vegetation N: P ratio: a new tool to detect the nature of nutrient limitation. J Appl Ecol 33:1441-1450

McGroddy ME, Daufresne T, Hedin LO (2004) Scaling of C:N:P stoichiometry in forests worldwide: implication of terrestrial Redfield-type ratios. Ecology 85:2390-2401

Niklas KJ, Owens T, Reich PB, Cobb ED (2005) Nitrogen/phosphorus leaf stoichiometry and the scaling of plant growth. Ecol Lett 8:636-642

Reich PB, Oleksyn J (2004) Global patterns of plant leaf N and P in relation to temperature and latitude. PNAS 101:11001-11006

Ren SJ, Yu GR, Tao B, Wang SQ (2007) Leaf nitrogen and phosphorus stoichiometry across 654 terrestrial plant species in NSTEC. Environ Sci 28:2665-2673 (In Chinese with English abstract)

Robertson GP, Vitousek PM (1981) Nitrification potentials in primary and secondary succession. Ecology 62:376-386

SOSS (The State Office for Soil Survey) (1993) The soil categories of China, vol I. China Agriculture Press, Beijing (In Chinese)

Thompson K, Parkinson JA, Band SR, Spencer RE (1997) A comparative study of leaf nutrient concentrations in a regional herbaceous flora. New Phytol 136:679-689

Tilman D (1982) Resource competition and community structure. Princeton University Press, Princeton

Tilman D (1997) Community invisibility, recruitment limitation, and grassland biodiversity. Ecology 78:81-92

Vitousek PM, Matson PA, Cleve KV (1989) Nitrogen availability and nitrification during succession, primary, secondary and old field series. Plant Soil 115:229-239

Zhang C, Tian HQ, Liu JY, Wang SQ, Liu ML, Pan SF, Shi XZ (2005) Pools and distributions of soil phosphorus in China. Glob Biogeochem Cycles 19:GB1020. doi:10.1029/2004 GB002296

Zheng SX, Shangguan ZP (2006) The spatial distribution pattern of plant leaf nutrient composition on the Loess Plateau. Nat Sci Progress 16:965-973 (In Chinese with English abstract) 